\title{
RADIOPROTECTIVE EFFECTS OF AMIFOSTINE (WR-2721) OR CYSTAMINE ON RADIATION DAMAGE AND ITS REPAIR IN RATS WHOLE BODY EXPOSED TO FISSION NEUTRONS
}

\author{
Pavel Kuna $^{1}$, Milan Dostál ${ }^{2}$, Otakar Neruda ${ }^{2}$, Karel Volenec ${ }^{3},+$ Ivan Vodička ${ }^{4}$, Leoš Navrátil ${ }^{1}$, Pavel Petýrek ${ }^{2}$, \\ Václav Svoboda ${ }^{5},+$ Jan Šimša ${ }^{2}$, Jiřina Vávrová ${ }^{2}$, Jindřiška Heřmanská ${ }^{6}$, Zdeněk Prouza ${ }^{7}$, Pavel Pitterman $^{7}$, Evžen Listik ${ }^{8}$, \\ František Spurnȳ", Josef Knajfl ${ }^{2}$, František Podzimek ${ }^{2}$, Stanislav Spelda ${ }^{2}$, Jan Österreicher ${ }^{2}$, František Konrád ${ }^{2}$, \\ Renata Havránková
}

University of South Bohemia, České Budějovice, Faculty of Health and Social Studies, Czech republic; Department of Radiology and Toxicology ${ }^{1}$; Purkyně Military Medical Academy Hradec Králové, Czech Republic: Department of Radiobiology ${ }^{2}$; Ella-CS, Hradec Králové, Czech Republic ${ }^{3}$; Charles University in Prague, Faculty of Medicine in Hradec Králové, Czech Republic: Department of Medical Biophysics ${ }^{4}$; University Hospital in Hradec Králové, Czech Republic: Department of Radiation Oncology ${ }^{5}$; Charles University in Prague, $2^{\text {nd }}$ Medical Faculty, Czech Republic: Department of Biophysics and Nuclear Medicine ${ }^{6}$; The State Office for Nuclear Safety, Praha, Czech Republic ${ }^{7}$; Institute of Nuclear Research Rež

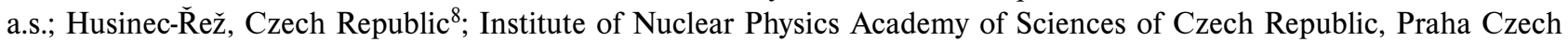
Republic $^{9}$

Summary: Sulphur containing radioprotective drugs amifostine (gammaphos, WR-2721) or cystamine (disulfide of meracaptoethylamine) of Czechoslovak production were examined in whole body fission neutrons irradiated rats in the thermal column of reactor VVR-S. Using the split-dose technic the first sublethal neutron dose in the range 1-2 Gy was followed by second lethal exposures in the two time intervals ( 3 or 6 days) using whole body fission neutrons irradiations ( 3 days interval) or whole body $\gamma$-irradiations ( 6 days interval) for $\mathrm{LD}_{50 / 30}$ evaluation within next 30 days survival observation. In other experiments the mean survival time (MST) in days was estimated in different rats group, when animals were whole body fission neutrons irradiated twice with 3-days interval using the total lethal doses of 4 or 5 Gy. Protected rats received amifostine (160 mg.kg-1 i.p. and $200 \mathrm{mg} . \mathrm{kg}^{-1}$ i.m.) or cystamine (40 mg.kg ${ }^{-1}$ i.p. and 50 mg.kg ${ }^{-1}$ i.m. $)$, control rats obtained saline 20 min before beginning of irradiation in the amount of $0.5 \mathrm{ml} .100 \mathrm{~g} \mathrm{~g}^{-1}$ of the rat's body weight. Nonsignificant DRF value 1.13 for WR-2721 i.p. was calculated in survival studies in rats twice neutron irradiated with 3 days interval (DRF 1.04 for cystamine). Chemical protectors were administered before each neutron exposure. MST of twice neutron lethal iradiated rats was prolonged not regularly by radioprotectors tested. WR-2721 and cystamine i.m. were not able to increase 6 days reparation processes after sublethal 2 Gy fission neutrons whole body irradiated rats.

Key words: Fission neutrons; Radioprotective drugs; Amifostine; WR-2721; Cystamine; Rats; Reparation of radiation injury

\section{Introduction}

Amifostine (WR-2721) and cystamine administered parenterally were ineffective in our studies with single whole body fission neutrons irradiation of rats, when integral postradiation injury as 7 or mostly 30 days lethality and mean survival time of died animals served for the assessement of radioprotective effectivneess after the comparison of control non-protected and protected rats using probit analysis method (11).

In earlier experiments WR-2721 was effective in mice exposed to the same fission-spectrum neutrons (12). DRF was $1.26(1.12-1.41)$ when amifostine was i.m. injected 20 min before irradiation in the dose $200 \mathrm{mg} . \mathrm{kg}^{-1}$. Increased dose of WR-2721 to $300 \mathrm{mg} \cdot \mathrm{kg}^{-1}$ elevated the DRF value to 1.48 (1.33-1.66).

Both chemical radioprotectors synthetized in Czechoslovakia occured clear radioprotective effect in single whole body gamma irradiated small laboratory rodents as mice $(3-8)$ and rats $(13,15)$. WR-2721 was effective in the protection of bone morrow in case of repeated exposures of mice to gamma rays, in different regimen of fractionation of irradiation with 6-hours interval for a total treatment 4 times. WR-2721 was given 30 min before each radiation fraction at a dose 200 mg.kg-1 i.p. (24). 24-hours interval for repeated whole body gamma irradiation during 5 days and the doses of WR-2721 50 or 300 mg. $\mathrm{kg}^{-1}$ used Petýrek et al. (16) with very good protective effect on bone marrow in mice. 
The results about radioprotective effectiveness of cystamine and WR-2721 against neutron whole body irradiation in other mammals than mice are not accessible with exceptions. Our atempt for the explanation of lack of radioprotective efficiency of both chemical compounds in the case of fission neutrons whole body irradiation of rats was divided in two orientations: an analysis of initial radiation injury in control and protected animals and the evaluation of the ability of protectors to improve the repair postradiation processes. Split-dose technic, used in our earlier experiments (26), was the base for a judgement of reparative processes in presented experiments. Fission neutrons were produced in thermal column of the reactor VVR-S in Institute of nuclear research in Řež. Gamma irradiation from ${ }^{60} \mathrm{Co}$ source Chisotron and the laboratories of the department of radiobiology of Purkyně Military medical academy (PMMA) in Hradec Králové served for these experiments.

\section{Methods}

Animals. Male and female rats of Wistar strain (180$230 \mathrm{~g}$ ) were delivered by the breeding centre Velaz, Prague. The animals were kept in propylen boxes, five rats in one, fed with standard pellet diet DOS-2b-St and supplied with drinking water ad libitum. The animals were adapted on vivarium conditions during 10-14 days.

Irradiation. The rats were irradiated by gamma rays from ${ }^{60} \mathrm{Co}$ source Chisotron (Chirana). The distance between the source and the middle of the animal was $100 \mathrm{~cm}$. Exposure was measured in roentgens by FRT clinical dosimeter "Otto Schön" No. 27012 in the air. The dose in Gy was calculated according to formula $1 \mathrm{~Gy}=95.7 \mathrm{R}$. Fission neutrons were produced and applied in thermal column of the reactor VVR-S (USSR) with mean energy 0.9-1.0 MeV with $30-40 \%$ fluency participation of moderate neutrons $(\mathrm{E}<0.1 \mathrm{MeV})$. The contamination with gamma rays was 22-30\%. The dose rate of whole irradiation was determined on 0.453 Gy.min ${ }^{-1}$. Each rat was irradiated in own propylen cell, which was fixed on rotating panel, 15 rats in individual boxes for one radiation procedure. The rate of 4 cycles per $1 \mathrm{~min}$ was used. This turning was necessary for relatively uniform fission neutrons irradiation of the rat body.

Two irradiations with 3 days interval were applied for the evaluation of reparative ability of irradiated rats following the first exposure to fission neutrons.

In the initial experimental study the animals were treated i.p. with saline (control group) or with protectors (experimental groups) before the first non-lethal standard dose of $1 \mathrm{~Gy}$ of fission neutrons. After 3 days the same animals were irradiated using the increased doses of fission neutrons (1, 2 and $3.5 \mathrm{~Gy}$ ) following the same i.p. pretreatment by saline, WR-2721 (160 mg. $\left.\mathrm{kg}^{-1}\right)$ or cystamine (40 mg. $\left.\mathrm{kg}^{-1}\right)$ and the lethal doses $\left(\mathrm{LD}_{5 / 30}, \mathrm{LD}_{50 / 30} \mathrm{LD}_{95 / 30}\right)$ of both irradiations together were estimated by probit-logarithmic method. In the case of higher reparation after the first irra- diation injury of rat organism, the higher dose of second irradiation for the equieffective injury was presumed.

In the second experiment the 3 days interval between the first and the second fission neutron irradiations was used too. The first dose was 1 or $2 \mathrm{~Gy}$, the second one 2-4 Gy and mean survival time (MST) in days served as criterion of lethal radiation injury. Before each neutron irradiation the rats were pretreated i.m. by saline, WR-2721 (200 mg. $\left.\mathrm{kg}^{-1}\right)$ or cystamine ( $\left.50 \mathrm{mg} . \mathrm{kg}^{-1}\right) 20 \mathrm{~min}$ before beginning of irradiation.

In the last (3rd) experiment the first fission neutrons irradiation by standard 2 Gy dose was performed 20 minutes following i.m. administration of saline, WR-2721 (200 mg. $\left.\mathrm{kg}^{-1}\right)$ or cystamine $\left(50 \mathrm{mg} . \mathrm{kg}^{-1}\right)$. The second whole body gamma irradiation using increased doses (3-8 Gy) was given 6 days latter without any pretreatment and the lethal gamma rays doses were calculated for 7 or 30 days postirradiation intervals.

Lethality studies used 30-days survival observation. From the lethaliy data the lethal doses $\mathrm{LD}_{5 / 30}, \mathrm{LD}_{50 / 30}$ and $\mathrm{LD}_{50 / 30}$ and relative radiation effect with $95 \%$ confidence limits were calculated by the probit-logarthmic method (18) in the Laboratory of medical cybernetics of PMMA. The radiation dose reduction factors (DRF) of parenterally injected radioprotective substances for 30-days postirradiation lethality are reverse values of the relative radiation effect in rats premedicated with tested protective agents (amifostine and cystamine).

Chemicals used. Radioprotective drugs amifostine, WR2721, chemicaly S-2-(aminopropylamino)-ethyl-phosphorothioic acid and cystamine (disulfide-2-mercaptoethylamine) dihydrochloride were synthetized by C. Krajčovič (13). The doses of cystamine. $2 \mathrm{HCl}$ are given in the the dose of cystamine base. The chemicals were dissolved in saline (Imuna, Šarišské Michalany, Slovakia) and administered without $\mathrm{pH}$ modification.

\section{Results}

Twice administrations of radioprotective drugs before repeated exposures of rats to fission neutrons were tested in two experimental series. In the first experiment the rats were irradiated by the $1^{\text {st }}$ standard sublethal dose of $1 \mathrm{~Gy}$ of fission neutrons and following 3 days by the second exposure with increased doses 1,2 and 3.5 Gy of fission neutrons (Tab. 1). The radioprotectors or saline were injected intraperitoneally $20 \mathrm{~min}$ before each whole body irradiation in the same group of female rats. No significant radioprotective effects of amifostine (WR-2721) or cystamine were demonstrated in described irradiation conditions and repeated protectors i.p.administration, but calculated lethal doses were regularly higher in protected rats in comparison with control saline treated rats. The DRF values were calculated in rats for WR-2721 on 1.13, for cystamine on 1.04 respectively.

In the second experiment of this experimental serie the female rats were irradiated twice by fission neutrons with 
Tab. 1: Values of lethal doses of twice whole body fission neutrons irradiations with 3 days interval. 20 min before each irradiation the same rats groups received i.p. saline, WR-2721 $\left(160 \mathrm{mg} . \mathrm{kg}^{-1}\right)$ or cystamine $\left(40 \mathrm{mg} . \mathrm{kg}^{-1}\right)$. Season: AugustSeptember, dose rate 0.453 Gy.min ${ }^{-1}$. Numbers in brackets are $95 \%$ confidence limits.

\begin{tabular}{|c|c|c|c|c|c|c|c|}
\hline \multirow[t]{2}{*}{$\begin{array}{l}\text { Treatment before } \\
\text { each irradiation }\end{array}$} & \multirow{2}{*}{$\begin{array}{l}1^{\text {st }} \text { dose } \\
\text { of fission } \\
\text { neutrons } \\
(\mathrm{Gy})\end{array}$} & \multirow{2}{*}{$\begin{array}{l}2^{\text {nd }} \text { dose } \\
\text { of fission } \\
\text { neutrons } \\
\text { (Gy) }\end{array}$} & \multirow[t]{2}{*}{ Lethality } & \multicolumn{3}{|c|}{$\begin{array}{l}\text { Lethal doses of both } \\
\text { fission neutrons } \\
\text { irradiations }(\mathrm{Gy})\end{array}$} & \multirow[t]{2}{*}{ DRF } \\
\hline & & & & $\mathrm{LD}_{5 / 30}$ & $\mathrm{LD}_{50 / 30}$ & $\mathrm{LD}_{95 / 30}$ & \\
\hline $\begin{array}{l}\text { Saline } \\
\text { i.p. }\end{array}$ & $\begin{array}{l}1 \\
1 \\
1 \\
\end{array}$ & $\begin{array}{c}1 \\
2 \\
3.5 \\
\end{array}$ & $\begin{array}{c}0 / 10 \\
1 / 8 \\
10 / 10 \\
\end{array}$ & $\begin{array}{c}2.24 \\
(1.42- \\
4.48) \\
\end{array}$ & $\begin{array}{c}3.37 \\
(2.82- \\
4.48) \\
\end{array}$ & $\begin{array}{l}5.05 \\
(3.98- \\
10.37)\end{array}$ & 1.00 \\
\hline $\begin{array}{l}\text { WR-2721 } \\
\text { i.p. }\end{array}$ & $\begin{array}{l}1 \\
1 \\
1\end{array}$ & $\begin{array}{c}1 \\
2 \\
3.5 \\
\end{array}$ & $\begin{array}{c}0 / 10 \\
0 / 9 \\
7 / 10 \\
\end{array}$ & $\begin{array}{l}2.27 \\
(1.04- \\
2.87)\end{array}$ & $\begin{array}{c}\mathbf{3 . 9 6} \\
(3.20- \\
5.86)\end{array}$ & $\begin{array}{c}6.91 \\
(5.04- \\
23.35)\end{array}$ & $\begin{array}{r}\mathbf{1 . 1 3} \\
(0.83- \\
1.54)\end{array}$ \\
\hline $\begin{array}{l}\text { Cystamine } \\
\text { i.p. }\end{array}$ & $\begin{array}{l}1 \\
1 \\
1 \\
\end{array}$ & $\begin{array}{c}1 \\
2 \\
3.5 \\
\end{array}$ & $\begin{array}{l}0 / 10 \\
0 / 10 \\
9 / 10 \\
\end{array}$ & $\begin{array}{c}2.29 \\
(1.43- \\
2.79) \\
\end{array}$ & $\begin{array}{c}\mathbf{3 . 5 2} \\
(2.91- \\
4.61) \\
\end{array}$ & $\begin{array}{c}5.41 \\
(4.25- \\
10.59) \\
\end{array}$ & $\begin{array}{r}\mathbf{1 . 0 4} \\
(0.78- \\
1.37) \\
\end{array}$ \\
\hline
\end{tabular}

Tab. 2: Mean survival times of female rats irradiated twice by whole body fission neutrons exposures with 3 days interval.

$20 \mathrm{~min}$ before each irradiation the same groups of rats received i.m. saline (S), WR-2721 (W) in the dose of 200 mg.kg-1 and cystamine (C) in the dose of 50 mg.kg-1. Season: August-September, dose rate 0.453 Gy.min ${ }^{-1}$. Numbers in brackets are $95 \%$ confidence limits.Letter $a$ indicates statistically significant difference from rats group received before irradiation saline only, letter $b$ from rats group received before irradiation amifostine (WR-2721). Numbers in brackets are $95 \%$ confidence limits.

\begin{tabular}{|l|c|rc|}
\hline $\begin{array}{l}\text { Scheme } \\
\text { of experiment }\end{array}$ & $\begin{array}{l}\text { Sum of the } \\
\text { doses (Gy) }\end{array}$ & \multicolumn{2}{|c|}{$\begin{array}{c}\text { Mean survival time } \\
\text { (days) }\end{array}$} \\
\hline S 1 Gy + S3 Gy & 4 & $\mathbf{1 1 . 0 9}$ & $(9.09-13.09)$ \\
W 1 Gy + W 3 Gy & 4 & $\mathbf{1 5 . 0 9}$ & $(10.67-19.51)$ \\
C 1 Gy + C 3 Gy & 4 & $\mathbf{1 2 . 7 3}$ & $(9.12-16.33)$ \\
\hline S 1 Gy + S4 Gy & 5 & $\mathbf{5 . 5 3}$ & $(4.70-6.37)$ \\
W 1 Gy + W 4 Gy & 5 & $\mathbf{7 . 5 0}$ & $(5.94-9.07)$ a \\
C 1 Gy + C 4 Gy & 5 & $\mathbf{7 . 9 3}$ & $(5.90-9.97)$ a \\
\hline S 2 Gy + S2 Gy & 4 & $\mathbf{1 4 . 1 1}$ & $(10.37-17.91)$ \\
W 2 Gy + W 2 Gy & 4 & $\mathbf{1 5 . 5 0}$ & $(6.29-24.71)$ \\
C 2 Gy + C 2 Gy & 4 & $\mathbf{1 2 . 5 8}$ & $(9.79-15.38)$ \\
\hline S 2 Gy + S3 Gy & 5 & $\mathbf{7 . 6 4}$ & $(5.34-9.95)$ \\
W 2 Gy + W 3 Gy & 5 & $\mathbf{5 . 2 0}$ & $(4.24-6.16)$ a \\
C 2 Gy + C 3 Gy & 5 & $\mathbf{9 . 0 0}$ & $(6.73-11.27) ~ b$ \\
\hline
\end{tabular}

Tab. 3: Values of lethal doses of whole body gamma irradiation for 30-days observation period in male rats, exposed 6 days following the first whole body fission neutrons irradiation in the dose of $2 \mathrm{~Gy} .20 \mathrm{~min}$ before the $1^{\text {st }}$ gammaneutron irradiation the rats received in the group of 15-20 animals saline, WR-2721 (200 mg. kg $\left.{ }^{-1}\right)$ or cystamine (50 mg.kg-1) i.m. Season: July - September, dose rate 0.453 Gy. $\min ^{-1}$ ). Numbers in brackets are $95 \%$ confidence limits.

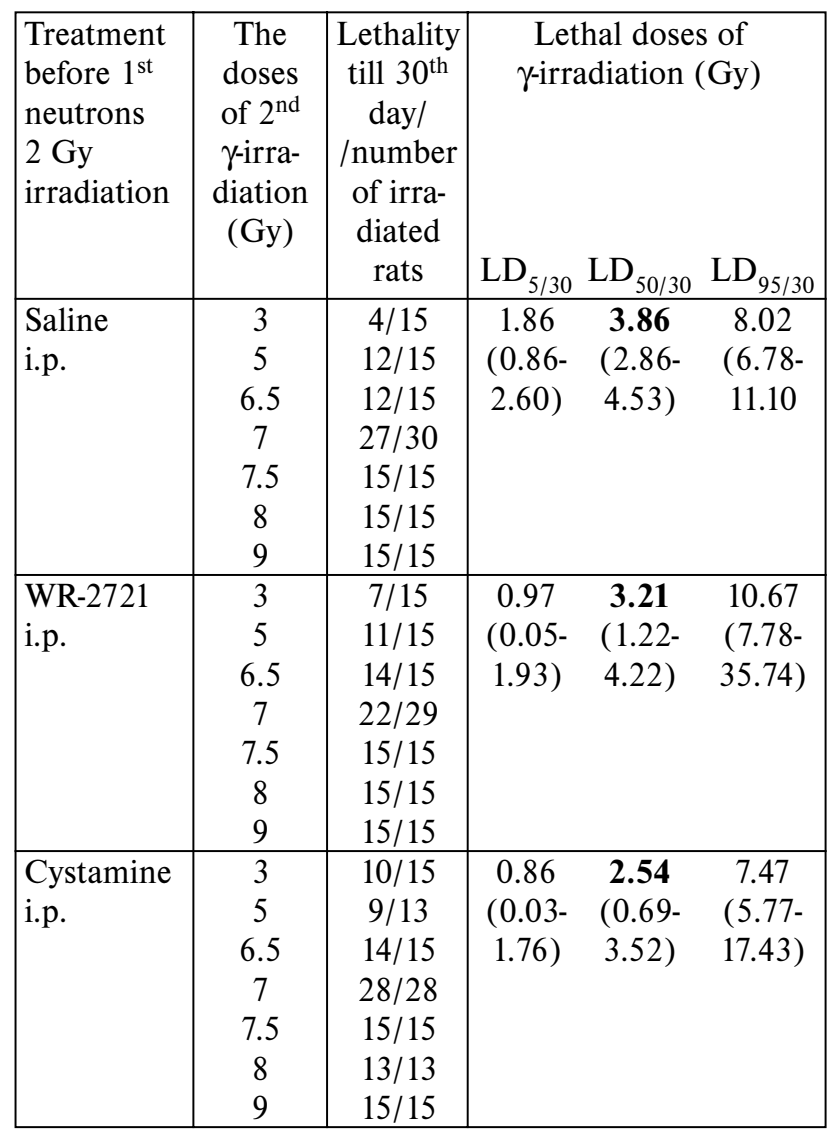


the same time interval of 3 days. The rats received $20 \mathrm{~min}$ before each exposures in VVR-S reactor intramuscularly saline, WR-2721 (200 mg. $\left.\mathrm{kg}^{-1}\right)$ or cystamine $\left(50 \mathrm{mg} . \mathrm{kg}^{-1}\right)$. Mean survival time of rats following the second fission neutrons exposure served for evaluation of postradiation injury of control and protected rats. Altogether the rats were irradiated by the lethal doses of 4 or 5 Gy (Tab. 2). MST was not regularly prologed using amifostine or cystamine before each neutron irradiation, but significantly. For statistical comparison of the duration of survival time interval in days in examined rats groups the tables of Genes (1) were used.

In the last ( $3 \mathrm{rd}$ ) experiment for the evaluation of the reparation processes the male rats were used. Whole body fission neutrons irradiation was performed in the standard sublethal dose of 2 Gy with i.m. praetreatment by saline, WR-2721 (200 mg.kg-1) or cystamine (50 mg.kg-1), $20 \mathrm{~min}$ before the start of exposure. Following 6 days the rats were exposed without any treatment by increased doses of whole body gamma irradiation (3-8 Gy). The lethality of gamma irradiated rats were followed untill the $30^{\text {th }}$ day after $\gamma$ rays exposure (Tab. 3).

Lethality values after the $2^{\text {nd }} \gamma$-irradiation in grays estimated following 30-days observation excluded any positive influence of both tested protectors on 6-days reparation processes in rats exposed to $2 \mathrm{~Gy}$ of fission neutrons whole body irradiation. Similarly the calculation of lethal doses during 7-days observation period post the $2^{\text {nd }} \gamma$-rays exposure, which explaines dominantly the intestinal neutrons postradiation injury and its reparation (Tab. 4), had the same conclusion: no effect of radioprotective drugs tested was occured.

Tab. 4: Values of lethal doses of whole body gamma irradiation for 7-days observation period in male rats, exposed 6 days following the first whole body fission neutrons irradiation in the dose of $2 \mathrm{~Gy} .20 \mathrm{~min}$ before the $1^{\text {st }}$ gammaneutrons irradiation the rats received the same amount of WR-2721 or cystamine i.m. as mentioned in the Tab. 3 (the same animals used for the calculation).

\begin{tabular}{|c|c|ccc|}
\hline $\begin{array}{c}\text { The doses } \\
\text { of } 2^{\text {nd }} \\
\gamma \text {-irradiation } \\
(\mathrm{Gy})\end{array}$ & $\begin{array}{c}\text { Lethality till } \\
7 \text { day/number } \\
\text { of irradiated } \\
\text { rats }\end{array}$ & \multicolumn{3}{|c|}{$\begin{array}{c}\text { Lethal doses of } \\
\gamma \text {-irradiation }(\mathrm{Gy})\end{array}$} \\
\hline 3 & $0 / 15$ & 2.91 & $\mathbf{8 . 6 0}$ & 25.45 \\
5 & $4 / 15$ & $(0.29-$ & $(6.75-$ & $(13.80-$ \\
7 & $5 / 15$ & $4.28)$ & $22.04)$ & $1296)$ \\
9 & $8 / 15$ & & & \\
\hline 3 & $1 / 15$ & 3.42 & $\mathbf{8 . 4 1}$ & 20.66 \\
5 & $1 / 15$ & $(1.50-$ & $(6.77-$ & $(13.08-$ \\
7 & $4 / 15$ & $4.53)$ & $13.47)$ & $93.71)$ \\
9 & $10 / 15$ & & & \\
\hline 3 & $0 / 15$ & 4.30 & $\mathbf{8 . 3 9}$ & 16.36 \\
5 & $0 / 13$ & $(2.56-$ & $(6.99-$ & $(11.72-$ \\
7 & $2 / 15$ & $5.34)$ & $11.71)$ & $41.82)$ \\
9 & $11 / 15$ & & & \\
\hline
\end{tabular}

\section{Discussion}

According to results presented in our experiments on rats, the radioprotective substances amifostine and cystamine were not able to improve reparative processes of initial radiation damage induced by sublethal doses of fission neutrons, when 3 or 6 days intervals of reaparation were chosen. The rats received the first dose of fission neutrons in the range of 1 to $2 \mathrm{~Gy}$ of whole body exposure with or without protectors praetreatment. The values of $\mathrm{LD}_{50 / 30}$ of single whole body fission neutrons irradiation in reactor VVR-S for non-protected rats were determined on 3.34 and $3.95 \mathrm{~Gy}$ and the doses 1.5 or $2 \mathrm{~Gy}$ did not cuased lethal effect within 30 day postradion period (11). Following 3 days the second increased doses of fission neutrons also with or without protective drugs premedication were applied. In non-protected saline control rats the value of $\mathrm{LD}_{50 / 30}$ remained simillar as in single neutron irradiated rats -3.37 Gy. The division of the sum doses of neutrons into two fractions had not favorable effect nor on radiopotective effects of WR-2721 or cystamine in twice neutron irradiated rats with 3 dyas interval. Lethal doses of gamma rays were apllied without radioprotectors praetreatment 6 days latter following fission neutrons whole body irradiation. Presented $\mathrm{LD}_{50 / 30}$ value of whole body gamma irradiadet rats $3.86 \mathrm{~Gy}$ was lower about $50 \%$ in comparison with $\mathrm{LD}_{50 / 30}$ value in single whole body gamma irradiated rats. They were determined on 6.71, 7.49 and 8.44 Gy (15). This finding indicates great remained postneutrons injury, which chemical radioprotectors are not able to decrease.

In our experiments on rats this split-dose method was used for an evaluation of the radioprotective effect of cystamine and its combination with calcium gluconate on the reparative processes following head X-rays irradiation $(26,27)$. The intervals $80 \mathrm{~min}, 1$ day, 3 days and 7 days were chosen for reparation of the first head irradiation injury. The repair of the radiation damage towards the $1^{\text {st }}$ day had an exponential course and on the 7 th day more than $50 \%$ of the initial damage was repaired. In rats whole body irradiated by fission neutrons Rudakov and Taciy (18) demonstrated the half time of reparation of neutron radiation injury on $11.2 \pm 0.4$ days. It was 1.5 times more in comparison with the reparation following X-irradiation. Sverdlov (23) introduced in mice $T_{1 / 2}$ of reparation on 2 or 6 days, when lethal doses $\left(\mathrm{LD}_{50 / 30}\right)$ used as criterion of neutrons injury. An explanation for such differences could be found in different kind of neutrons spectrum used and the greatness of the dose of the first irradiation, from sublethal to $2 / 3$ of $\mathrm{LD}_{50 / 30}$, which reparation is tested with next irradiation(s).

Cystamine was ineffective in the prevention of the development of the early abscopal effects of the mice head gamma irradiation with the dose of $20 \mathrm{~Gy}$ (9). Cystamine lessed certain changes and it especially speeded up the onset of the reparation of the dry matter of brain and also certain distant nonirradiated radiosensitive structure as leucocyte 
count in peripheral blood, cellularity of the femur bone marrow and small inestine and the dry matter of salivary glands, spleen and testes. WR-2721 was more effective than cystamine in combination with the head shielding of the gamma lethal irradiated mice as in the case of whole body exposure (10).

The positive results with chemical radioprotection in neutron irradiated mice $(2,19-23)$ we also prooved with WR-2721 (11).The analysis of early changes following whole body fission neutrons and an evaluation of radioprotective ability of WR-2721 and cystamine on these events as well as on the course of postradiation changes in radiosensitive tissues could explain worse effectiveness of sulphur-containing chemical radioprotective substances in neutron irradiated rats.

\section{References}

1. Genes VS. Tables of significant differences between groups of observations according to quality indicators (in Russian). Moscow: Meditsina, 1964:80.

2. Grdina DJ, Wright BJ, Carnes BA. Protection by WR-151327 against late-effect damage from fission-spectrum neutrons. Radiat Res 1991;128(suppl 1):124-7.

3. Kuna P. Protection of hemopoietic tissue in whole body gamma irradiated mice by cystamine given intramuscularly. Radiobiol Radiother (Berlin) 1981;22: 315-7.

4. Kuna P. Radioprotective effectivness of cystamine administered intramuscularly to mice (in Russian). Radiobiologya 1982;22:517-9.

5. Kuna P. Appearance of radioprotective effect of gammaphos (WR-2721) in mice (in Czech). Cas Lek ces 1982;121:912-4.

6. Kuna P. Duration and degree of radioprotection of WR-2721 in mice following its intraperitoneal, intramuscular and subcutaneous administration. Radiobio Radiother (Berlin) 1983;24:357-64.

7. Kuna P. Radioprotection of small intestine and spleen hemopoiesis by gammaphos (WR-2721) or cystamine in whole body gamma irradiated mice. Biologia (Bratislava) 1983;23:273-82.

8. Kuna P. Chemical radioprotection (in Czech). Praha: Avicenum,1985:148. (Translated into Russian. Moscow: Meditsina, 1989:190)

9. Kuna P. Modification of the abscopal effects of gamma irradiation of the head of mice by cystamine (in Czech). Cs Radiol 1986;40:345-52.

10. Kuna P. Radioprotective effect of WR-2721 (gammaphos) or cystamine in nonuniform lethal gamma irradiated mice. Radiobiol Radiother (Berlin) 1986; 27:761-9.

11. Kuna P, Dostál M, Neruda O et al. Radioprotective effects of gammaphos (WR 2721 ) and cystamine in the case of whole-body irradiation of mice by fission neutrons (in Czech). Sborn lek (Praha) 1988;90:110-6.

12. Kuna P, Dostál M, Neruda O et al. Radioprotective effects of amifostine (WR 2721 ) or cystamine in single whole body fission neutron irradiated rats. J Appl Biomed 2004;2:43-9.
13. Kuna P, Krajčovič C. Acute toxicity and radioprotective effectiveness of gammaphos (WR-2721) in rats (in Czech). Cas Lek ces 1981;120:776-81.

14. Kuna P, Neruda O, Navrátil L, Matzner J, Žišková R. Nuclear Terrorism. J Appl Biomed 2003;1:55-9.

15. Kuna P, Volenec K, Vodička I, Dostál M. Radioprotective and hemodynamic effects of WR-2721 and cystamine in rats: Time course studies. Neoplasma 1983; 30:349-57.

16. Petýrek P, Osterreicher J, Vávrová J. The radioprotective effects of WR-2721 in mice exposed to sublethal fractionated dosis of gamma-radiation. In: BaumstarkKhan C et al., eds. Fundamentals for the Assessment of Risk from Environmental Radiation. The Netherlands: Kluwer Academic Publishers, 1999:433-6.

17. Pospišil M. Pharmacological radiation protection. In: Baumstark-Khan $\mathrm{C}$ et al., eds. Fundamentals for the Assessement of Risk from Envirnmental Radiation. The Netherlands: Kluwer Academic Publishers, 1999:411-20.

18. Roth Z, Josífko M, Malý V, Trčka V. Statististical methods in experimental medicine (in Czech). Praha: Státní zdravotnické nakladatelství, 1962:589.

19. Rudakov NP, Taciy YuA. Biophysics and radiobiology (in Russian). Kiev: Naukova dumka, 1972:3:43.

20. Sedlmeier H, Metzger E, Jentzsch U, Weitzenegger E. Schutzeffekt von Aminoprolylamino-athylthiophosphat (WR- 2721) bei Neutronen-, Gamma- oder Rontgenbestrahlung von Mausen. Strahlentherapie 1981;157:685-91.

21. Sigdestad CP, Grdina DJ, Connor AM, Hanson WR. A comparison of radioprotection from three neutron cources and ${ }^{60} \mathrm{Co}$ by WR-2721 and WR-151327. Radiat Res 1986;106:224-33.

22. Sigdestad CP, Connor AM, Sims CS. Modification of neutron-induced hematopoietic effects by chemical radioprotectors. Int J Radiat Oncol Biol Phys 1992; 22:807-11.

23. Steel LK, Walden TL Jr, Huges HN, Jackson III WE. Protection of mice against mixed fission neutron- $\gamma(\mathrm{n}: \gamma=1: 1)$ irradiation by WR-2721, 16, 16-dimethyl PGE $_{2}$, and the combination of both agents. Radiat Res 1988;115:605-8.

24. Sverdlov AG. Biological effects of neutrons and chemical protection (in Russian) Leningrad: Nauka, 1974:224.

25. Travis EL, Fang M-Z, Basic I. Protection of mouse bone marrow by WR-2721 after fractionated irradiation. Int J Radiation Biol Phys 1988;15:377-82.

26. Volenec K, Vodička I, Chmelař V, Kuna P. Rat lethality after local irradiation of the head with simultaneous screening of the CNS (in Czech). Sborn Ved Pr Lek Fak UK v Hradci Králové 1984;27(suppl 4):431-5.

27. Volenec K, Vodička I, Kuna P. Radiation damage and its repair after local X-ray irradiation of the head of the rats protected with cystamine. Sborn Ved Pr Lek Fak UK v Hradci Králové 1984;27:519-33.

Submitted September 2003.

Accepted October 2003.

Prof. MUDr. Pavel Kuna, DrSc., Department of Radiology and Toxicology, Faculty of Social and Health Studies, University of South Bohemia, Matice školské 17, 37000 České Budějovice, Czech Republic. e-mail pavel.kuna@tiscali.cz 